\title{
MERI-DIES ACCORDING TO LATIN AUTHORS FROM CICERO TO ANTHONY OF PADUA: THE VARIOUS USES OF A COMMONPLACE ETYMOLOGY*
}

\author{
Tim Denecker \\ Research Foundation - Flanders (FWO), Leuven/Ghent
}

\begin{abstract}
The etymology of meridies stands as a commonplace in the Latin literary tradition. The present article aims to expand on the evidence collected by Maltby in his 1991 A Lexicon of Ancient Latin Etymologies - primarily by extending its historical scope into the Middle Ages - and to interpret and contextualise the body of source material thus established. It is shown that in the relevant sources (chronologically ranging from Cicero [born $106 \mathrm{BC}$ ] to Anthony of Padua [died 1231]), the mericomponent is mostly reduced to merus or to medius, but that combinations and minor alternative explanations frequently occur. It also becomes clear that the etymology of meridies is discussed and put to use in a broad variety of text types, and in very diverse historical and cultural contexts. Lastly, it is argued that the case of meridies is illustrative of the difference between 'ancient' and 'modern' conceptions of etymology.
\end{abstract}

\section{Introduction}

The etymology of meridies, 'midday, noon, south', has commonplace status throughout the Latin literary tradition, including technical genres and exegetical works. In Maltby's presentation of the relevant source material, three possible accounts of the word's history can be discerned. According to what seems to be the oldest etymology, the components medius and dies (a noun which may have masculine or feminine gender) were contracted to medidies, which was subsequently altered by dissimilation - for the sake of euphony - into meridies. An alternative etymology has it that meridies

* This article originated from a research project on Latin language manuals from Late-Antique and Early-Medieval Western Christianity, funded through a postdoctoral mandate from the KU Leuven Research Council (2015-2016) and a postdoctoral fellowship from the Research Foundation - Flanders (FWO) (20162019). Thanks are due to Pierre Swiggers and the two anonymous referees of Acta Classica for their valuable comments. All translations in this article are mine. Series abbreviations have been resolved in the bibliography. 
should be analysed as merus dies, the 'purest' or 'brightest' part of the day. A third explanation connects the meri- component to Greek $\mu$ ćpos, 'part, share'. ${ }^{1}$ On the basis of searches in online databases, ${ }^{2}$ the present article aims (1) to supplement the series of relevant passages listed by Maltby by extending his historical scope, and (2) to interpret and contextualise the body of source material thus established: how do Latin authors etymologise meridies, and how do they put this etymology to use in their specific historical and cultural circumstances? It will become clear that the explanations listed by Maltby are not seldom combined, and that minor alternative explanations also occur.

\section{Antiquity}

At the origin of the series of relevant comments stands Cicero (106-43 BC), ${ }^{3}$ who explicitly connects the dissimilation occurring in medidies to the criterion of euphony. In Orator 157 (written in 46 BC) Cicero suggests that medidies was altered into meridies because the original form sounded less pleasant (quod erat insuavius) - most probably because of the repetition of the combination $d i{ }^{4}$ Only a couple of years later, the polymath Varro (116$27 \mathrm{BC}$ ), Cicero's contemporary and acquaintance, claims to rely on his own, first-hand observation. At 6.4 of his De lingua Latina (presumably published between 45 and $43 \mathrm{BC}$ ), Varro notes that the word meridies comes 'from the fact that it is the middle of the day (medius dies)', pointing out that 'the ancients (antiqui) said $d$, not $r$, in this word, as I have seen in Praeneste, engraved on a sundial (ut Praeneste incisum in solario vidi). ${ }^{5}$ Praeneste was a city in Sabine territory, and in Varro's opinion this probably added to the authority of his observation. Himself of Sabine provenance, Varro believed that the Latin language contained an old and important Sabine 'substratum'. 6

\footnotetext{
${ }^{1}$ Maltby 1991:381; and see the entry in TLL 8:839.

${ }^{2}$ Viz. the Library of Latin Texts (A and B), the Monumenta Germaniae Historica, the Archive of Celtic-Latin Literature (all these through the BREPOLiS Cross Database Searchtool), and the Patrologia Latina Database.

3 For the authors treated in the sections on Antiquity and Late Antiquity, biographical data are based on Der Neue Pauly, unless indicated otherwise.

${ }^{4}$ Ed. Reis 1971:58.

${ }^{5}$ Ed. Goetz and Schoell 1964:58; cf. Collart 1954:94-95; Pfaffel 1986:386; Adams 2007:170.

${ }^{6}$ Collart 1954:99-100, 233-43. In a rather indirect way, the medius etymology is also suggested by an entry in the De verborum significatu written by M. Verrius Flaccus in the time of the emperors Augustus (63 BC-14 AD) and Tiberius (42 BC$37 \mathrm{AD})$ - at least as it has been preserved in the epitome made by the Carolingian
} 
At some time during the reign of the emperor Nero (54-68 AD), the latter's elegantiae arbiter Petronius in $\S 37$ of his hybrid novel Satyricon has one of the characters claim that if she [Trimalchio's wife Fortunata] would tell him [Trimalchio] at bright midday (mero meridie) that it is dark, he would believe it.'7 The figura etymologica on meridies in this quotation is probably the oldest (but less than explicit) evidence we have of the merus etymology. ${ }^{8}$ In his Institutio oratoria 1.6.30 the Roman professor of rhetoric Quintilian (c. 35-c. 100) cites the question whether one should say meridies or medidies for 'midday' [so, from medius], as an example of the use of etymology in 'distinguishing barbarisms from correct words' (barbara ab emendatis ... discernere), that is, in establishing linguistic correctness. ${ }^{9}$ From this time on, meridies and its possible etymologies find their way into the broader tradition of (primarily technical) Latin writings. The example is reiterated by Velius Longus, a grammarian from the time of the emperor Hadrian (117-138 AD), who in his De orthographia puts the case of meridies pro medio die on a par with auriculae deriving from audiculae. ${ }^{10}$ The grammarian Censorinus, author of a lost De accentibus, in his De die natali liber (dating to the summer of 238) at 24.3 simply reduces meridies to medius dies. ${ }^{11}$

\section{Late Antiquity: Early Christian authors}

The etymology of meridies is dealt with rather frequently in the literature of Latin Early Christianity. Whereas the permutationes litterarum - that is, the operations of addition (adiectio), subtraction (detractio), permutation (transmutatio) and substitution (immutatio) of letters within a word ${ }^{12}-$ remain implicit in the instances discussed so far, they are explicitly connected to the word history of meridies in a very specific, argumentative context. The anonymous exegete dubbed 'Ambrosiaster', active in the city

grammarian Paul the Deacon (c. 720/30-c. 800), a pupil of Alcuin, on the basis of the earlier abridgement by Sextus Pompeius Festus, which presumably dates to the 2nd century AD. The entry at issue reads as follows: 'medialis they called a black sacrifice animal, which they slayed at midday (meridie)'; ed. Lindsay 1978:111.

${ }^{7}$ Ed. Buecheler 19638:40.

${ }^{8}$ Cf. ed. Guillaumin 2010:38 n. 159.

9 Ed. Radermacher and Buchheit 1965:44; cf. Von Fritz 1949:349; De Poerck 1970:209; Ax 2011:279.

${ }^{10} \mathrm{Ed}$. GL 7:71.

${ }^{11}$ Ed. Sallmann 1983:59.

12 Cf. Lausberg 19903:250-54 §462; Ax 1987. 
of Rome in the 370s and 380s,,$^{13}$ relies on the permutationes litterarum and quotes the case of meridies when arguing that Hebraeus as a glotto- and ethnonym derives from the personal name Abraham and not from Heber. ${ }^{14}$ The argument can be found in Ambrosiaster's Commentarius in epistulas Paulinas Philippenses 3.7.3 and reads as follows:

But the Hebrews are named after Abraham. For a letter was changed (immutata est enim littera) for the sake of euphony (propter sonum), so that they were called not Abraei but Ebraei, just as among the ancients (ut apud veteres), when people said (cum diceretur) medidie and it was harsh-sounding (et esset absurdum), a letter was changed (immutata est littera), so that people said (ut diceretur) meridie. ${ }^{15}$

The argument in the Commentarius is short and vague - vowel change ${ }^{16}$ is put on a par with consonant change, and propter sonum is in itself insufficient as an explanation - but becomes more evident when one looks at the elaborate (and therefore possibly earlier) version in Ambrosiaster's Quaestiones veteris et novi testamenti 108.5. Unlike in the Commentarius, Ambrosiaster here for the sake of argument prefers the form Habraham over Abraham, although this may also be due to a later scribal intervention. The exegete first states the opinion of his adversaries, namely that the name Heber sounds more like Hebrei than Habraham does, 'because they are called Hebrei not Habraei.'17 However, he replies to this that 'they are called Hebrei, not Heberei, while he was called Heber, not Hebrer.' In order to demonstrate, now, how Hebrei can derive from Habraham, Ambrosiaster argues that

... for the sake of euphony (propter sonum) a letter was changed (immutata est littera), so that they were called Hebrei instead of Habraei, because that sounds better (quia melius sonat); for those from Iuda, too, are called not Iudai but Iudaei. For whenever something seemed harsh-sounding (ubicumque enim absurdum visum est), a letter was changed (immutata est littera), so that the word

${ }^{13}$ Cf. Lunn-Rockliffe 2007:16.

${ }^{14}$ Cf. Denecker 2014:2-17; Eskhult 2014:318-21; and the discussion in Denecker 2017.

${ }^{15}$ Ed. CSEL 81/3:152; cf. Marangoni 2007:81.

$16 \mathrm{Viz}$. the one taking place in the first syllable, in the alteration from Abraei to Ebraei.

17 Unlike in the Commentarius, Ambrosiaster's observation here seems to concern the changes going on both in the first and in the second syllable, although scribal and editorial interventions may be involved in the alteration between $a e$ and $e$. 
would possess a suitable sound (ut vox sonum compositum haberet). For we say meridie instead of medidie and there are many comparable cases. ${ }^{18}$

In both accounts, the at-first-sight transparent dissimilation of medidies to meridies is quoted to illustrate the alleged triviality of the fact that words change for the sake of euphony. Twice it is quoted at the end of the relevant exposition, which seems to suggest that it is a textbook example known, or at least intelligible, to everyone. According to Lunn-Rockliffe, Ambrosiaster 'benefited from an education in the classics and forensic rhetoric.' ${ }^{19} \mathrm{He}$ may thus have known the case of meridies from Cicero or Quintilian, or simply have been aware of its commonplace status via the broader school tradition.

Around the same time, Rufinus (died 410) - a native of Aquileia who pursued his scholarly activities in a monastery in Palestine - proposes the alternative explanation in $\S 2$ of his translation of the Commentarium in Canticum canticorum by the Greek Church Father Origen of Alexandria ( $c$. 185-c. 253). ${ }^{20}$ His occasion for discussing the etymology of meridies is the Biblical verse Song of Songs (Cant.) 1:6 (in the Vulgate), which contains the words in meridie. Rufinus describes meridies as that time [of the day], when light is more copiously poured out over the world, and when it is mere day (quo merus est dies) and the light is purer and more flowery (et purior ac florulentior lux).'21 This appears to be our first explicit occurrence of the merus etymology - in the case of Petronius, it was only implied by the figura etymologica. Since Rufinus' translation is the only form in which Origen's commentary has been preserved, ${ }^{22}$ there may have been a 'precedent' for the etymology in Origen's Greek, but Rufinus may well have introduced it himself. The North-African Church Father Augustine (354-430) returns to the version of Cicero and Quintilian when, in his Locutiones in Heptateuchum Genesis 177, he reduces meridies to medius dies, without further motivation. ${ }^{23}$ In 6th-century Italy, the long-lived statesman and then monk

${ }^{18}$ Ed. CSEL 50:254-55. The text portion quoted is integrated in $\S 30$ of the 8thcentury Commentarius Wirziburgensis in Matthaeum necnon et glossae, which as such also reproduces the meridies example and its derivation from medidies. The electronic version of this Irish commentary in ACLL is based on Köberlin 1891, which was controlled by Bischoff 1954:251-53 n. 22.

${ }^{19}$ Lunn-Rockliffe 2007:62.

${ }^{20}$ Vogt 2002:528.

${ }^{21}$ Ed. GCS 33:137.

${ }^{22}$ Vogt 2002:530.

${ }^{23}$ Ed. CCSL 33:398. 
and scholar Cassiodorus (c. 485-c. 580 $)^{24}$ follows Augustine in doing so, namely in his Expositio psalmorum 54.18. ${ }^{25}$

It is at some time between Augustine and Cassiodorus that our clearest evidence for Maltby's third category, the $\mu$ ćpos etymology, is to be situated. In a pseudo-Chrysostomian homily on Psalm 90, which cannot be dated to before the second half of the 5 th century, ${ }^{26}$ the following exposition is given: 'Meridies is so called because it divides the day. For meros [cf. $\mu$ ćpos] is a divided part of the day (pars ... divisa diei), so that as much seems to go by as there remains until the end of the day.' Contrary to what Maltby's entry suggests, the author of the homily with this explanation also combines the medius etymology, when he adds: 'So since the sun then stands in the middle of the sky, it is called medius dies. ${ }^{27}$ The homily belongs to a collection of 30 or 31 homilies that have been transmitted among those by the prolific Greek Church Father John Chrysostom (probably 349-407), ${ }^{28}$ but were, in fact, composed by an unknown bishop in Africa or Southern Italy. ${ }^{29}$ Interestingly, the unproblematic derivation of a Latin word from a Greek one does seem to suggest that these homilies were delivered in an environment where, at this relatively late date, a certain degree of Latin-Greek bilingualism was not uncommon, perhaps indeed Southern Italy.

\section{Late Antiquity: the artigraphical tradition}

More extensive comments can be identified in the tradition of LateAntique grammars and literary commentaries. The famous Roman grammarian Aelius Donatus (born in Africa c. 310, died c. 380) in his commentary on Terence's Adelphoe - a commentary which has not preserved its original authorial form - at 5.3.62 ascribes the dissimilation to the veteres and observes that this was possible due to the 'affinity' which allegedly exists between the letters $r$ and $d$ (propter cognationem inter se harum litterarum) thus adding a new element to the explanation. ${ }^{30}$ Around the same time, the etymology is also commented upon by Nonius Marcellus, the language

\footnotetext{
${ }^{24}$ Bürsgens 2002:141.

${ }^{25}$ Ed. CCSL 97:494.

26 Windau 2002.

${ }^{27}$ Ed. PL suppl. 4/1:787.

${ }^{28}$ Dünzl and Kaczynski 2002:378-80.

29 Morin 1894:402 carefully suggested attributing this collection to John the Mediocre', Johannes Mediocris, Bishop of Naples around 533/5-553/5, but this suggestion is no longer maintained; cf. Windau 2002; Dünzl and Kaczynski 2002: 382.

${ }^{30}$ Ed. Wessner 1966:163.
} 
scholar from Tubursicum Numidarum in present-day Algeria, whose De compendiosa doctrina is to be situated in the late- 4 th or early-5th century AD. In Book 1 of this work (De proprietate sermonum), the author notes on p. $60 \mathrm{M}$ that 'meridies is evidently the middle of the day (manifeste medius dies)', referring explicitly to Cicero's Orator 157 and thus integrating the euphony argument. ${ }^{31}$ Donatus' and Nonius Marcellus' contemporary, Macrobius, discusses the case in his Commentarii in Somnium Scipionis 2.5.19, when dealing with the four cardinal points. With regard to the south, he writes that 'as if it were in a sense the medidies, with one letter changed (una mutata littera) it was called meridies.' ${ }^{32}$ In another work of his, the Saturnalia, Macrobius at 1.3.14 simply paraphrases ad meridiem as ad medium diei. ${ }^{33}$

Some time later, the example is taken up by Priscian, ${ }^{34}$ a native of Caesarea in Mauretania who was active as a professor of grammar in Constantinople until the first decades of the 6th century AD. In Book 1 of his major work entitled Institutiones grammaticae, Priscian mentions meridies as one of the cases where $d$ transit ... in $r^{35}$ In Book 4 of the same work, the grammarian points out that, in regard to the regular formation of deverbative adjectives on -idus,

... for the sake of alternation (alternitatis causa), which the Greeks

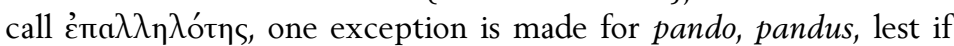
we would say pandidus, the one $d$ after the other (alterna $d$ ) in both successive syllables (in utraque continua syllaba) would sound bad (male sonet), and this both we and the Greeks usually shun in many cases (quod in multis solent tam Graeci quam nos evitare). They do not say Xapú $\beta \delta 1 \delta$ os, although the rule requires them to do so (quamvis exigat regula), but Xapú $\beta \delta \varepsilon \omega s$. And the Romans, too, following them, do not say huius Charybdidis, but huius Charybdis. Because of the same defect (eiusdem vitii causa) we do not say from that, what is mane, manunine, but matutine, from vitis vinetum, not vitetum, which seems, however, also to be derived (videtur esse derivatum) from vinea. Furthermore: meridies instead of medidies, from medius dies. ${ }^{36}$

${ }^{31}$ Ed. Lindsay 1964:84; cf. Solimano 1992.

${ }^{32}$ Ed. Willis 1994a:113.

33 Ed. Willis 1994b:12.

${ }^{34}$ For a collection of studies on Priscian's life, works and legacy, cf. Baratin et al. 2009.

${ }^{35}$ Ed. GL 2:35.

36 Ed. GL 2:136-37. 
Here again, meridies is added at the end of a longer series of examples, as an at-first-sight transparent case known to all readers. The etymology of meridies features prominently in the highly influential Etymologiae by Isidore, the polymath archbishop of Seville in Visigothic Spain (c. 560636). ${ }^{37}$ At 3.42.3 (in 'On the four parts of the sky'), 5.30 .15 (in 'On the days') and 13.1.6 (in 'On the world') of his encyclopaedia, Isidore reduces meridies, by way of medidies (quasi medidies) to medius dies. However, in these three passages he also adds the alternative explanation - perhaps going back to Rufinus' translation of Origen's commentary on Song of Songs (see above) - that at this time of the day, 'the sky shines brighter' (tunc purius micat aether) or 'the day is purer' (tunc purior dies est) - purus being a synonym for merus (merum enim purum dicitur) ${ }^{38} \mathrm{~A}$ peculiar case (possibly going back to a different source) can be identified at 20.3.3 (in 'On drinks'), where Isidore implicitly juxtaposes both explanations when noting: 'Hence we also believe that this time, which falls after the middle of the day (post medium diem), is called meridies, because it is bright (quod purum sit). ${ }^{39} \mathrm{~A}$ more elaborate discussion of the word's history (which is reminiscent of Velius Longus' exposition mentioned above) occurs at 17.7.2 of the Etymologiae (in 'On the proper names of trees'), where Isidore observes on laurus, 'laurel', supposedly deriving from laus, laudis, that

... among the ancients (apud antiquos), however, it was called laudea; later (postea), with the letter $d$ taken away ( $d$ littera sublata) and $r$ substituted (subrogata $r$ ), it was called laurus; just as in auriculae, which were initially (initio) called audiculae, and medidies, which is nowadays (nunc) called meridies. ${ }^{40}$

\section{The Middle Ages: encyclopaedic works}

With Isidore we have reached the dawn of the Middle Ages. For this period, one can distinguish four coherent 'context clusters' in which the etymology of meridies is discussed. Firstly, the etymology occurs in a number of encyclopaedic works, evidently due to the influence of Isidore's Etymologiae. This is clearly the case in the De universo by Hraban Maur or Rabanus Maurus (c. 780-856), a native of Mainz, in former ages renowned as the

37 Cf. Fontaine 1959-1983.

${ }^{38}$ Ed. resp. Gasparotto and Guillaumin 2009:103-5; Yarza Urquiola and Andrés Santos 2013:97-99; Gasparotto 2004:10.

${ }^{39}$ Ed. Guillaumin 2010:39.

${ }^{40}$ Ed. André 1981:81. 
praeceptor Germaniae, who strongly relies on Isidore's Etymologiae. ${ }^{41}$ In De universo, the prologue of Book 9 ('On the world and its four regions') repeats the double explanation of Isidore's Etym. 13.1.6; 42 Chapter 10.5 ('On the parts of the day') repeats that of Etym. 5.30.15;43 Chapter 19.6 ('On the proper names of trees') that of Etym. 17.7.2 (printed above);44 and Chapter 22.2 ('On drinks') that of Etym. 20.3.3.45 In other words, Hraban always reproduces the etymology from the thematically corresponding entry in Isidore's encyclopaedia. Some centuries later, Honorius of Augustodunum (c. 1080-c. 1154) - who was taught by Anselm of Canterbury and active in a (probably Irish) convent near Regensburg ${ }^{46}$ - in his Imago mundi 1.86 uses the standard phrase meridies quasi medidies, ${ }^{47}$ while at 2.26 combining the two major explanations: Meridies a media die; et dicitur quasi mera et pura dies. ${ }^{48}$ The etymology can furthermore be found in a reproduction of Isidore's Etym. 17.7.2 (see above) in Chapter 3.56 ('On trees') of a work entitled De bestiis et aliis rebus, the first two books of which were written by the Augustinian monk Hugo of Fouilloy (1100/10-1172/3), ${ }^{49}$ the last two by anonymous authors. ${ }^{50}$

\section{The Middle Ages: grammatical works}

Secondly, in the Middle Ages the etymology of meridies continues to be dealt with in the grammatical tradition, where the influence of Priscian's works is pervasive. The phrase meridies dicitur quasi medidies turns up in the commentary on Priscian's beginner's level De nomine pronomine et verbo by Remigius of Auxerre (c. 841-c. 908), the Carolingian grammarian and teacher active at the Benedictine school of Saint-Germain of Auxerre, and later at the cathedral schools of Reims and Paris. ${ }^{51}$ To this brief definition, Remigius, too, juxtaposes the alternative explanation that meridies is called so 'as if it were (quasi) mera dies, that is pura dies.' Unlike his predecessors, Remigius adds as an argument a mistaken equivalence between the Greek

${ }^{41}$ Ziolkowski 2006.

${ }^{42}$ Ed. PL 111:260.

${ }^{43}$ Ed. PL 111:290.

${ }^{44}$ Ed. PL 111:512.

${ }^{45}$ Ed. PL 1 11:595.

${ }^{46}$ Beyer de Ryke 2002.

47 Ed. PL 172:141.

${ }^{48}$ Ed. PL 172:150.

${ }^{49}$ Bautz 1990b.

${ }^{50}$ Ed. PL 177:112.

${ }^{51}$ Matter 1995. 


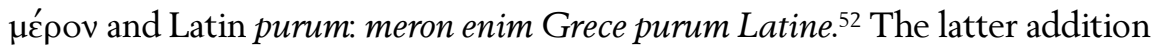
seems to go back to a confusion between the explanations respectively based on the Latin merus, 'pure' and Greek $\mu$ '́pos, 'part' (see above), which was possibly enhanced by a misinterpretation of Isidore's merum enim purum dicitur (see above). A more straightforward account is found in an 11thcentury glossed manuscript (Vat. Reg. Lat. 1578) of the same work of Priscian's. On folio $27^{\mathrm{r}}$ it is simply stated with reference to dies that 'hence meridies is composed (componitur), that is, media dies. ${ }^{53}$ An exceptionally critical account is given by the teacher of grammar and rhetoric Peter Helias (c. 1100-after 1166), who was born near Poitiers and active in Paris. ${ }^{54}$ In his Summa super Priscianum he states repeatedly (with minor variations) that 'meridies is composed (componitur) of medius and dies, with $d$ changed into $r$ (mutata $d$ in r)', and that 'what is also said, meridies as if it were mera dies, is an etymology rather than a compound (ethimologia potius est quam compositio). ${ }^{55}$ Klinck quotes this passage in order to illustrate that in medieval grammatical discourse, the term compositio (like derivatio) was reserved for those word explanations that followed more or less established linguistic patterns, while etymologia covered looser explanatory strategies (see my concluding remarks). ${ }^{56}$

Furthermore, the Northern-French grammarian Evrard of Bethune (died c. 1212) $)^{57}$ - or, more probably, one of his close collaborators - writes in Chapter 2 (De figuris barbarismi et solecismi) of the versified Graecismus that 'a word that sounds ugly (dictio turpe sonans) is itself called cacemphaton / as if one would say Tytides and medidies.' This relatively vague statement is elucidated in a marginal gloss on the Graecismus which 'was developed in the course of the 13th, and remained alive until the 15th century. ${ }^{158} \operatorname{In} \S 2.3$ on cacemphaton (within Chapter 2, De vitiis), this gloss reads as follows:

Likewise, if two syllables that are joined together (due syllabe simul iuncte) suffer an ugly sonority (turpem patiantur sonoritatem), as when one says Tydides and medidies - since according to correct analogy

\footnotetext{
${ }^{52}$ Ed. CCCM 171:20.

53 Jeudy 1992:64.

54 Kneepkens 2006:512.

${ }^{55}$ Ed. Reilly 1993:1.133 (quotation from this page), 1.150 and 1.354. In his indices, Reilly 1993:2.1142 also refers to a divergent statement on p. 132 line 57, but unfortunately I have not been able to identify the passage referred to, as there is no line 57 on p. 132.

${ }^{56}$ Klinck 1970:29, 44 with n. 32.

${ }^{57}$ Cf. Grondeux 2000.

${ }^{58}$ Ed. CCCM 225:V (tr. mine).
} 
(secundum rectam analogiam), that is, according to correct formation (secundum rectam formationem), we ought to say it so, because just as we say Eacides from Eacus, and just as Eacus has a c, so too Eacides, and just as Priamus has an $m$, so too Priamides, likewise we ought to say from Tydeus Tydides and medidies as if it were (quasi) media dies - but for the sake of euphony (causa euphonie) we say meridies and Tytides. ${ }^{59}$

The gloss again briefly touches on the case of medidies in the subsequent paragraph (2.4) on euphonia, now defining euphony as 'when one letter is changed into another (littera in litteram mutatur) for the sake of beautiful sonority (causa pulchre sonoritatis), as when one says meridies for medidies, and Tytides for Tydides. ${ }^{160}$ The appearance of the accurate terms sonoritas and euphonia in this gloss is noteworthy.

\section{The Middle Ages: works on computus and the calendar}

Thirdly, the etymology of meridies occurs in a group of works concerned with computus and the calendar. Chapter 8 ('On the day') of a $D e$ divisionibus temporum, perhaps composed by the Anglo-Saxon monk and scholar the Venerable Bede (c.673-735), ${ }^{61}$ reduces the meri-component to merus, since midday is the purest part of the day, and 'the ancients said merus for purus. ${ }^{62}$ Hraban Maur (see above) in Chapter 20 ('On the parts of the day') of his De computo - like the previous one conceived in a question-andanswer (magister-discipulus) format - uses exactly the same words to reduce meri- to merus, but has this explanation preceded by the alternative explanation that meridies goes back to medidies. ${ }^{63}$ This juxtaposition can also be found in Chapter 6 ('On time calculation') of another work in question-and-answer format, a Disputatio puerorum per interrogationes et responsiones perhaps to be attributed to Alcuin (c. 730/5-804), ${ }^{64}$ the intellectual leader of the so-called Carolingian Renaissance, ${ }^{65}$ as well as in an anonymous De computo. ${ }^{6}$ Likewise, the Southern-French Guillaume

\footnotetext{
${ }^{59}$ Ed. CCCM 225:151.

${ }^{60}$ Ed. CCCM 225:153.

${ }^{61}$ Brown 1998.

62 Ed. PL 90:657.

${ }^{63}$ Ed. CCCM 44:224.

${ }^{64}$ E.g. Brown 2006.

65 Ed. PL 101:1115.

${ }^{66}$ Ed. PL 129:1307.
} 
Durand the Elder (1230/1-1296) ${ }^{67}$ in his Rationale divinorum officiorum 8.6.2 (in the book on computus and the calendar) simply combines the two alternative etymologies: meridies dicitur quasi medidies, id est medius dies, vel quia tunc purior dies est. ${ }^{68}$ Isidore's Etym. 5.30 .15 (part of 'On the days') is the evident ultimate source for all of these witnesses, but this is explicitly indicated only by the treatise perhaps to be attributed to Bede, by the anonymous De computo, and by Durand. ${ }^{69}$

The Middle Ages: commentaries on Song of Songs (and some other ecclesiastical writings)

A fourth and last group of medieval works discussing the etymology of meridies consists of commentaries on Song of Songs, which presumably base themselves at least in part (directly or indirectly) on Rufinus' translation of Origen's commentary (see above). In the cases in point, one can discern a considerable degree of variation and innovation, an important new aspect being an allegorical interpretation of meridies as 'the brightest' or 'purest part of the day' with specific reference to spiritual purity or the 'brightness' of the Afterlife. A first clear instance of this approach can be found in the Expositio in Cantica canticorum by Honorius of Augustodunum (see above). At 1.6 in this commentary, Honorius reduces the meri- component both to media and to mera, explaining it, furthermore, as 'pure day (pura dies), when the sun shines bright (clarus) in the centre of heaven', and arguing that it symbolises 'the splendour of eternal clarity, in which Christ, the sun of justice, shines in the middle between the Father and the Holy Spirit. ${ }^{70} \mathrm{~A}$ remarkable case of the same approach can be found in Book 2 of the commentary on Song of Songs, probably authored by the 12th-century Cistercian monk Thomas of Vancelles. ${ }^{71}$ The exegete proposes a threefold exegesis of the meridies mentioned in Cant. 1:6, on the basis of a threefold etymology of the word, namely the apparently original maerens dies, followed by media dies and mera dies. Because of the new etymology at this late date and the innovative exegetical connections, the passage is here given in full:

67 Thibodeau 2006.

${ }^{68}$ Ed. CCCM 140B: 156

${ }^{69}$ As for Durand, cf. the apparatus fontium in CCCM 140B:156.

${ }^{70}$ Ed. PL 172:372.

${ }^{71}$ Madey 2000; cf. Klinck 1970:168 n. 22. 
Also, there is a threefold midday (meridies), according to the threefold interpretation of this noun: the first is the clarity (claritas) of contemplatives who until now exert themselves in this [earthly] pilgrimage; the second is the clarity (claritas) of the saints who, freed from their bodies, are until now in expectation; the third, that of the angels and the saints who will see God more clearly (clarius) than the second, since [they see Him] face to face, having already celebrated their resurrection. The first midday (primus ... meridies) is so called as if it were maerens dies, since in it we mourn (maeremus) our sins, and we deserve (meremur [!]) the growths of virtues; the second midday (secundus ... meridies) is so called as if it were medidies, that is, media dies, since its clarity (claritas) is brighter (clarior) than the first, but more obscure than the third; the third midday (tertius ... meridies) [is so called] as if it were mera dies, since it is brighter (clarior) than the others. ${ }^{72}$

It should be noted that the maerens dies etymology (intertwined with an implicit mereri explanation) is very 'semantically' oriented when compared to the other, more 'formal' ones, and that the threefold etymology serves as the basis for a model of three degrees of virtue, which is probably backed by the notion of Trinity. In Book 1 of the same commentary, the author had simply glossed the words in meridie as in mera die. ${ }^{73}$

There are some further relevant cases within this 'context cluster'. Aelred (1110-1167) - a Cistercian monk in Rievaulx (Yorkshire), where he became abbot in 114774 - in $\S 12$ of his Sermo 169 (on the assumption of Mary) alludes to Cant. 1:6. In doing so, he glosses the words in meridie as mero et pleno et vero die, and to this attaches a spiritualising interpretation: 'where there is bright light and true peace and complete happiness.'75 Likewise, Gilbert Foliot (c. 1110-1187) - a Benedictine monk who became Bishop of Hereford and later of London ${ }^{76}$ - in his Expositio in Cantica canticorum 1.6 explains meridies as dies medius, while also attaching a notion of spiritual brightness to this explanation. ${ }^{77} \mathrm{~A}$ little later, Peter of Celle (died 1182) - who became Abbot of the Saint-Remi monastery in Reims in 1162 and Bishop of Chartres in $1180^{78}$ - in his Sermo 13 (on the purification of Mary) also quotes Cant. 1:6. He glosses meridies as mera dies, and interprets

\footnotetext{
${ }^{72}$ Ed. PL 206:100-1.

${ }^{73}$ Ed. PL 206:60.

${ }^{74}$ Nouzille 2002.

${ }^{75}$ Ed. CCCM 2C:544.

${ }^{76}$ Brooke 2004.

${ }^{77}$ Ed. PL 202:1 192-93.

78 Zinn 1995.
} 
this as an allegory for the eternal life, which is characterised by 'the full and perfect clarity of the vision of God's glory' and 'the full and perfect charity of God's love'. ${ }^{79}$

Apart from these passages, meridies is reduced to medius dies at 54.19 of the Expositio psalmorum by Bruno, Bishop of Würzburg (c. 1005-1045) this time only in passing and without specific argumentative value, as is the case in Cassiodorus' work of the same title (see above).$^{81}$ Lastly, an utterly confused version of the juxtaposition of medius and merus occurs at 1.5 of the sermon on the 16th Sunday after Pentecost by the Franciscan preacher and theologian Anthony of Padua (Fernando de Bulhoes, c. 1195-1231). ${ }^{82}$ The passage reads as follows: Meridies dictus, quasi medies, ${ }^{83}$ idest [sic] medius dies; vel quia meridies est, idest [sic] purior. Merum enim Graece, purum dicitur Latine. ${ }^{84}$ Because of the latter mistaken claim, the author may have drawn (directly or indirectly) on Remigius of Auxerre (see above), but the structure of the sentences quoted points towards a more direct Isidorian influence. ${ }^{85}$ Here again, the confusion may have been enhanced (independently or not) by a misinterpretation of Isidore's merum enim purum dicitur (see above). The 'bookish' and uncritical character of Anthony's statement contrasts sharply with the pertinent observations by Cicero and Varro with which this survey began. This aligns well with the broader mediaeval conception of knowledge, which generally attaches greater importance to the quantity or accumulation of information than to its quality or critical strength.

\section{Conclusion}

Without a doubt, the etymology of meridies continued to be dealt with in the literature of the Early Modern period. However, for a solid investigation of the meridies question in this period, scholarship needs to await a fuller digital coverage and searchability of Neo-Latin texts. It should be emphasised that for the Middle Ages, too, the present investigation remains largely limited to the literary production insofar as it has been digitised. For now, this article has shown how the etymology of meridies, as an (at first sight)

\footnotetext{
${ }^{79}$ Ed. PL 202:674.

${ }^{80}$ Bautz 1990a.

${ }^{81}$ Ed. PL 142:217.

82 Turley 2006.

$83 \mathrm{Sic}$, but according to the critical apparatus the reading meridies is also attested.

${ }^{84}$ Ed. Costa et al. 1979:2.255.

${ }^{85}$ Cf. Costa et al. 1979:2.255 n. 74.
} 
transparent commonplace or 'textbook' example, circulated widely historically and geographically - in Latin literature from Antiquity onwards, and how it was appropriated over and again in different scholarly, theoretical and argumentative contexts, ranging from grammars and literary commentaries, treatises on computus (often in question-and-answer format) and encyclopaedic works, to exegetical commentaries and sermons. The strong connection between the etymology of meridies and a number of very specific text types is remarkable, as is the fact that the etymology apparently circulated ever more widely (almost 'centrifugally') and remained 'productive' through the Middle Ages.

Furthermore, the case of meridies aptly illustrates an important difference between ancient and modern conceptions of etymology. ${ }^{86}$ In present-day historical linguistics, etymology is oriented towards the reconstruction of a historical root, via established sound laws; alternative reconstructions are therefore mostly seen as mutually exclusive. ${ }^{87}$ To the contrary, in its 'ancient' conception - which endured into the Early Modern period at least - etymology had a strong ontological and epistemological relevance, but was also very speculative in nature..$^{88}$ It served as a rather loose heuristic strategy in establishing the essence of things and, hence, the 'true' grounds for their names. ${ }^{89}$ Accordingly, alternative versions of a word's history were not necessarily regarded as mutually exclusive, but could be seen as complementary, thus contributing to a better and more exhaustive understanding of the referent's essence.

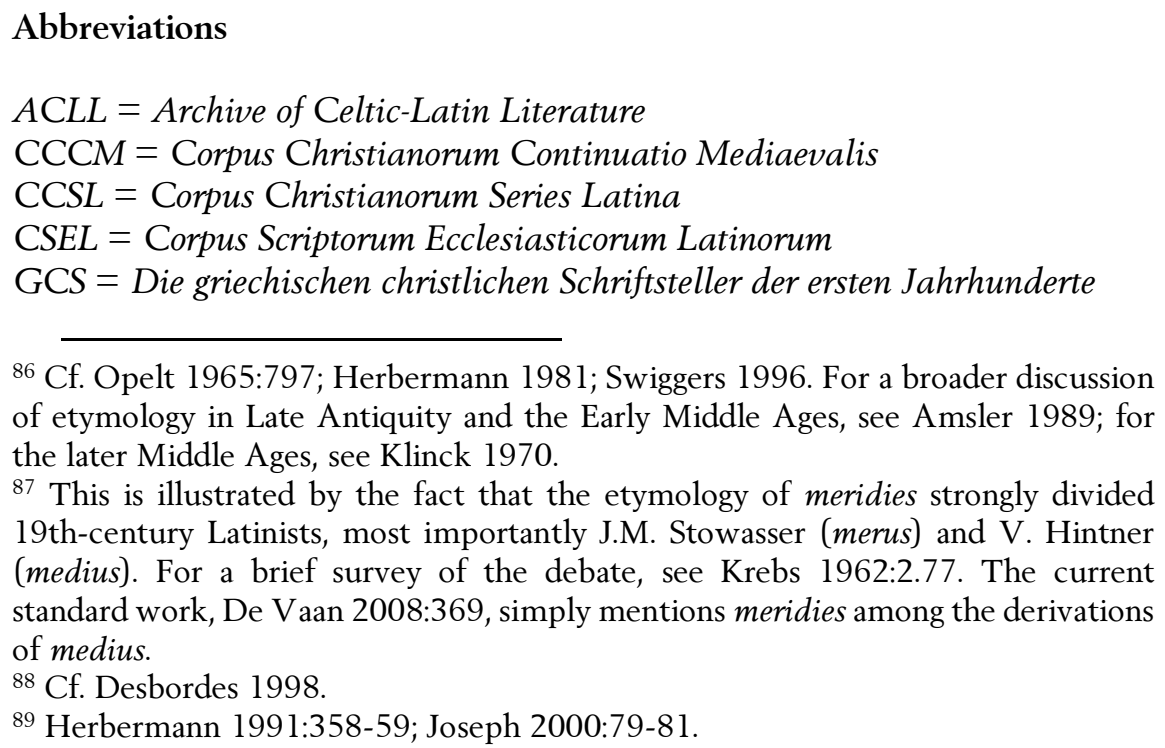


$\mathrm{GL}=$ Grammatici Latini (H. Keil)

$P L=$ Patrologia Latina (J.P. Migne)

$T L L=$ Thesaurus linguae Latinae

\section{Editions cited}

André, J. (ed.) 1981. Isidore de Séville, Étymologies. Livre XVII: De l'agriculture. Texte établi, traduit et commenté [...]. Paris.

Buecheler, F. (ed.) 1963․ Petronii Saturae [...]. Adiectae sunt Varronis et Senecae Saturae similesque reliquiae. Berlin and Zürich.

Costa, B., Frasson, L. and Luisetto, I. (edd.) 1979. S. Antonii Patavini, O. Min. Doctoris Evangelici Sermones dominicales et festivi ad fidem codicum recogniti [...]. 3 vols. Padova.

Gasparotto, G. (ed.) 2004. Isidoro di Siviglia, Etimologie. Libro XIII: De mundo et partibus. Edizione, traduzione e commento [...]. Paris.

Gasparotto, G. and Guillaumin, J.-Y. (edd.) 2009. Isidore de Séville, Étymologies. Livre III: De mathematica. Texte établi par G. Gasparotto avec la collaboration de J.-Y. Guillaumin, traduit et commenté par J.-Y. Guillaumin. Paris.

Goetz, G. and Schoell, F. (edd.) 1964. M. Terenti Varronis De lingua Latina quae supersunt [...] accedunt grammaticorum Varronis librorum fragmenta. Amsterdam.

Guillaumin, J.-Y. (ed.) 2010. Isidore de Séville, Étymologies. Livre XX: De penu et instrumentis domesticis et rusticis. Texte établi, traduit et commenté [...]. Paris.

Lindsay, W.M. (ed.) 1964. Nonii Marcelli De compendiosa doctrina libros XX [...]. Volumen I, Il. I-III, argumentum, indicem siglorum et praefationem continens. Hildesheim.

Lindsay, W.M. (ed.) 1978 [1913]. Sexti Pompei Festi De verborum significatu quae supersunt cum Pauli epitome [...]. Leipzig.

Radermacher, L. and Buchheit, V. (edd.) 1965 [1907]. M. Fabi Quintiliani Institutionis oratoriae libri XII [...]. Pars prior libros I-VI continens [...]. Leipzig.

Reilly, L. (ed.) 1993. Petrus Helias, Summa super Priscianum, 2 vols. Toronto.

Reis, P. (ed.) 1971 [1932]. M. Tulli Ciceronis scripta quae manserunt omnia, fasc. 5: Orator [...]. Stuttgart. 
Sallmann, N. (ed.) 1983. Censorini De die natali liber ad Q. Caerellium, accedit anonymi cuiusdam Epitoma disciplinarum (Fragmentum Censorini) [...]. Leipzig.

Wessner, P. (ed.) 1966 [1905]. Aeli Donati Commentum quod fertur Terenti, accedunt Eugraphi Commentum et Scholia Bembina, vol. II [...]. Stuttgart.

Willis, J. (ed.) 1994a [1970²]. Ambrosii Theodosii Macrobii Commentarii in Somnium Scipionis [...]. Stuttgart.

Willis, J. (ed.) 1994b [19702]. Ambrosii Theodosii Macrobii Saturnalia, apparatu critico instruxit, In Somnium Scipionis commentarios selecta varietate lectionis ornavit Iacobus Willis. Stuttgart and Leipzig.

Yarza Urquiola, V. and Andrés Santos, F.J. (edd.) 2013. Isidoro de Sevilla, Etimologías. Libro V: De legibus - De temporibus. Introducción, edición crítica, traducción y notas [...]. Paris.

\section{Bibliography}

Adams, J.N. 2007. The Regional Diversification of Latin 200 BC-AD 600. Cambridge.

Amsler, M.E. 1989. Etymology and Grammatical Discourse in Late Antiquity and the Early Middle Ages. Amsterdam and Philadelphia, Pa.

Ax, W. 1987. 'Quadripertita ratio: Bemerkungen zur Geschichte eines aktuellen Kategoriensystems (adiectio-detractio-transmutatio-immutatio).' In D.J. Taylor (ed.), The History of Linguistics in the Classical Period, 17-40. Amsterdam and Philadelphia, Pa.

Ax, W. 2011. Quintilians Grammatik (Inst. orat. 1,4-8): Text, Übersetzung und Kommentar. Berlin and Boston, Mass.

Baratin, M., Colombat, B. and Holtz, L. (edd.) 2009. Priscien: Transmission et refondation de la grammaire. De l'antiquité aux modernes. Turnhout.

Bautz, F.W. 1990a [1975]. 'Bruno, Bischof von Würzburg, Heiliger.' In Bautz and Bautz 1990:1.774-75.

Bautz, F.W. 1990b. 'Hugo von Fouilloy.' In Bautz and Bautz 1990:2.114041.

Bautz, F.W. and Bautz, T. (edd.) 1990. Biographisch-Bibliographisches Kirchenlexikon. Hamm, Herzberg and Nordhausen.

Beyer de Ryke, B. 2002. 'Honorius Augustodunensis, 1080 - 1157.' In C. Gauvard, A. de Libera and M. Zink (edd.), Dictionnaire du Moyen Âge, 689-90. Paris.

Bischoff, B. 1954. 'Wendepunkte in der Geschichte der lateinischen Exegese im Frühmitteltalter.' SEJG 6:189-281. 
Brooke, C.N.L. 2004. 'Foliot, Gilbert (c. 1110-1187).' In H.C.G. Matthew and B. Harrison (edd.), Oxford Dictionary of National Biography, 20.21821. Oxford.

Brown, G.H. 1998. 'Bede the Venerable (ca. 673-735).' In P.E. Szarmach and C.E. Karkov (edd.), Medieval England: An Encyclopedia, 114-17. New York and London.

Brown, G.H. 2006. 'Alcuin (ca. 730/35-804).' In Emmerson and ClaytonEmmerson 2006:18-20.

Bürsgens, W. 2002. 'Cassiodor.' In Döpp and Geerlings 2002³:141-43.

Collart, J. 1954. Varron grammairien latin. Paris.

Denecker, T. 2014. 'Heber or Habraham? Ambrosiaster and Augustine on language history.' REAug 60:1-32.

Denecker, T. 2017. Ideas on Language in Early Latin Christianity: From Tertullian to Isidore of Seville. Leiden and Boston, Mass.

De Poerck, G. 1970. 'Etymologia et origo à travers la tradition latine.' In Anamnêsis: Gedenkboek Prof. Dr. E.A. Leemans, 191-228. Brugge.

Desbordes, F. 1998. 'La pratique étymologique des Latins et son rapport à l'histoire.' In C. Buridant (ed.), L'étymologie de l'antiquité à la renaissance [= Lexique 14], 69-79. Lille.

De Vaan, M. 2008. Etymological Dictionary of Latin and the Other Italic Languages. Leiden and Boston, Mass.

Döpp, S. and Geerlings, W. (edd.) $2002^{3}$. Lexikon der antiken christlichen Literatur. Freiburg, Basel and Wien.

Dünzl, F. and Kaczynski, R. 2002. 'Johannes Chrysostomus.' In Döpp and Geerlings 2002 $: 378-85$.

Emmerson, R.K. and Clayton-Emmerson, S. 2006 (edd.), Key Figures in Medieval Europe: An Encyclopedia. New York and London.

Eskhult, J. 2014. 'The primeval language and Hebrew ethnicity in ancient Jewish and Christian thought until Augustine.' REAug 60:291-347.

Fontaine, J. 1959-1983. Isidore de Séville et la culture classique dans l'Espagne wisigothique, 3 vols. Paris.

Grondeux, A. 2000. Le Graecismus d'Evrard de Béthune à travers ses gloses: Entre grammaire positive et grammaire spéculative du XIII ${ }^{e}$ au XVe siècle. Turnhout.

Herbermann, C.-P. 1981. 'Moderne und antike Etymologie.' Zeitschrift für vergleichende Sprachforschung 95:22-48.

Herbermann, C.-P. 1991. 'Antike Etymologie.' In P. Schmitter (ed.), Geschichte der Sprachtheorie. Vol. 2: Sprachtheorien der abendländischen Antike, 353-76. Tübingen.

Jeudy, C. 1992. 'A glossed manuscript of Priscian's Institutio, Vatican, MS Reg. Lat. 1578.' In L. Smith and B. Ward (edd.), Intellectual Life in the 
Middle Ages: Essays presented to Margaret Gibson, 61-69. London and Rio Grande, Ohio.

Joseph, J.E. 2000. Limiting the Arbitrary: Linguistic Naturalism and its Opposites in Plato's Cratylus and Modern Theories of Language. Amsterdam and Philadelphia, Pa.

Kibler, W.W., Zinn, G.A. and Earp, L. 1995 (edd.), Medieval France: An Encyclopedia. New York and London.

Klinck, R. 1970. Die lateinische Etymologie des Mittelalters. München.

Kneepkens, C.H. 2006. 'Peter Helias.' In J.J.E. Gracia and T.B. Noone (edd.), A Companion to Philosophy in the Middle Ages, 512-13. Malden, Mass.

Köberlin, K. 1891. Eine Würzburger Evangelienhandschrift. Augsburg.

Krebs, J.P. 1962 [Photomechanischer Nachdruck der 7. von J.H. Schmalz überarbeiteten Auflage von 1905]. Antibarbarus der lateinischen Sprache, nebst einem kurzen Abriß der Geschichte der lateinischen Sprache und Vorbemerkungen über reine Latinität. Basel and Stuttgart.

Lausberg, H. 19903. Handbuch der literarischen Rhetorik: Eine Grundlegung der Literaturwissenschaft. Stuttgart.

Lunn-Rockliffe, S. 2007. Ambrosiaster's Political Theology. Oxford.

Madey, J. 2000. 'Thomas von Vancelles (Thomas Cisterciensis).' In Bautz and Bautz 1990:17.1372-73.

Maltby, R. 1991. A Lexicon of Ancient Latin Etymologies. Leeds.

Marangoni, C. 2007. Supplementum etymologicum Latinum I. Trieste.

Matter, E.A. 1995. 'Remigius of Auxerre (ca. 841-ca. 908).' In Kibler, Zinn and Earp 1995:793.

Morin, G. 1894. 'Étude sur une série de discours d'un évêque [de Naples ?] du VI ${ }^{e}$ siècle.' RBen 11:385-402.

Nouzille, P. 2002. 'Aelred de Rievaulx, 1110-1167.' In C. Gauvard, A. de Libera and M. Zink (edd.), Dictionnaire du Moyen Âge, 12. Paris.

Opelt, I. 1966. 'Etymologie.' In RAC 6:797-844.

Pfaffel, W. 1986. 'Wie modern war die varronische Etymologie?' Historiographia Linguistica 13:381-402.

Solimano, G. 1992. 'Meridies (Non. 723 L.).' Studi Noniani 14:219-42.

Swiggers, P. 1996. 'L'étymologie: Les transformations de l'étude historique du vocabulaire aux Temps Modernes.' In P. Schmitter (ed.), Geschichte der Sprachtheorie. Vol. 5: Sprachtheorien der Neuzeit II: Von der Grammaire de Port-Royal (I660) zur Konstitution moderner linguistischer Disziplinen, 352-85. Tübingen.

Thibodeau, T.M. 2006. 'William Durandus (c. 1230 or 1231-1 November 1296).' In Emmerson and Clayton-Emmerson 2006:668-69.

Turley, T. 2006. 'Anthony of Padua, Saint (c. 1195-1231).' In Emmerson and Clayton-Emmerson 2006:40-42. 
Vogt, H.J. 2002. 'Origenes.' In Döpp and Geerlings 2002³:528-36.

Von Fritz, K. 1949. 'Ancient instruction in "Grammar" according to Quintilian.' AJPh 70:337-66.

Windau, B. 2002. 'Ps.-Johannes Chrysostomus/Chrysostomus Latinus.' In Döpp and Geerlings 20023:385.

Zinn, G.A. 1995. 'Peter of Celle (d. 1182).' In Kibler, Zinn and Earp 1995: 723.

Ziolkowski, J.M. 2006. 'Hrabanus Maurus (ca. 780-February 4, 856).' In Emmerson and Clayton-Emmerson 2006:333.

tim.denecker@kuleuven.be 